\title{
NON - TRADITIONAL FORMS OF TOURISM IN SLOVAKIA AS A CONCEPT OF COMPETITIVENESS
}

\author{
Tünde DZUROV VARGOVÁ* \\ University of Prešov in Prešov, Department of Tourism and Hotel Management, \\ Konštantínova 16,080 01 Prešov, Slovakia, e-mail: tunde.dzurov.vargova@smail.unipo.sk \\ Peter GALLO \\ University of Prešov in Prešov, Department of Tourism and Hotel Management, \\ Konštantínova 16,08001 Prešov, Slovakia, e-mail: peter.gallo@unipo.sk \\ Milena ŠVEDOVÁ \\ University of Prešov in Prešov, Department of Tourism and Hotel Management, \\ Konštantínova 16, 08001 Prešov, Slovakia, e-mail: milena.svedova@unipo.sk \\ Eva LITAVCOVÁ \\ University of Prešov in Prešov, Department of Mathematical Methods and Managerial Informatics, \\ Konštantínova 16,080 01 Prešov, Slovakia, e-mail: eva.litavcova@unipo.sk

\section{Martina KOŠIKOVÁ} \\ University of Prešov in Prešov, Department of Mathematical Methods and Managerial Informatics, \\ Konštantínova 16, 08001 Prešov, Slovakia, e-mail: martina.kosikova@ smail.unipo.sk
}

\begin{abstract}
Citation: Dzurov Vargová, T., Gallo, P., Švedová, M., Litavcová, E., \& Košíková, M. (2020). NON - TRADITIONAL FORMS OF TOURISM IN SLOVAKIA AS A CONCEPT OF COMPETITIVENESS. GeoJournal of Tourism and Geosites, 30(2spl), $801-807$. https://doi.org/10.30892/gtg.302spl04-508
\end{abstract}

\begin{abstract}
Tourism is an industry that is developing dynamically worldwide, and Slovakia, which has significant potential in the area, is no exception. In order for a country to become competitive in tourism, it must follow the prevailing trends and continually carry out innovative activities, under which we also consider non-traditional forms of tourism. The aim of this article is to analyze the importance and address the future development of non-traditional forms of tourism in Slovakia (food tourism, health tourism, adventure tourism, dark tourism, etc.), to further examine the impact on the country's economy, sustainability and competitiveness. The article focuses on the demand for these forms of tourism from the perspective of visitors. Using hypotheses we found the statistical dependence (of the $\mathrm{p}$ value comparison) between the respondents (men and women of different age groups) and their preference for specific unusual forms of tourism. For the analy sis of specific objectives we used data collected using a questionnaire on unusual forms of tourism and their development in Slovakia. The subsequent processing and presented results also show how complex the segmentation of the tourism market is, how differentiated and variable the needs and motivation factors of tourism participants are, and how new interests and needs in tourism are emerging dynamically. The results of our survey show the need for more research to explore the ever-changing needs and conditions in tourism industry in order to fully understand the nontraditional tourism with its potential, benefits, message and value of present and future generations.
\end{abstract}

Key words: Tourism, unusual forms of tourism, efficiency, sustainable development

$* * * * * *$

\section{INTRODUCTION}

In the conditions of market economy all business entities, which can be viewed as socio-economic systems (SES), must be competitive (Ginevicius, 2019). Competitiveness can be considered from both the economic and psychological point of view (Piotrowska, 2019). Tourism is an important sustainable industry in the economy that optimizes the industrial structure and may become an important element of sustainable economic development policy (Błażejowski et al., 2019). The effort of each country is to help develop this industry in an effective way (Šenková and Šambronská, 2014). Tourism, as a phenomenon of the third millennium, is based on many elements that only highlight its broad nature. Draskovic et al., (2016) agree that tourism not only affects economic aspects but also the social aspects in general. For the optimal functioning of the economic system, the optimism of its participants is very important (Belás et al., 2014). Tourism makes it possible to travel and gain new experiences, to travel without barriers, to escape from everyday stereotypes and to independently gain and then disseminate knowledge (Šambronská et al., 2016). According to Drossosa and Tsotsolas (2014), tourism is composed of activities, services and industries that bring about travel experience: transport, accommodation, catering, entertainment, activities for individuals or groups, as well as all providers of services aimed at tourists. Customer expectation also plays an important role in a customer's assessment of tourism (Suchanek and Kralova, 2018; Pachura et al., 2018). At present, we are experiencing some great changes to the tourism market decreasing interest in the mass form of tourism and increased interest in individual forms of travel. Slovakia has suitable natural, historical and cultural predispositions for the development of tourism thanks to its unusual nature, history, and especially hospitable people. Its diverse regions offer the widest variety of activities. The paper should be written in the IMRaD structure. With regard to the development of unusual forms of tourism, it is also necessary to keep track of the risks that tourism brings. In the long run, this investment will bring profits and increase the value of the business - which is the main objective of the business owners after all (Dobrovič et al., 2018). The SME segment has its own characteristics and entails disadvantages that transform into business risk. This risk can be divided into market risk (lack of market space for market risk), own production, financial risk (weak access to finance), operational risk (failure to handle processes), (Belas et al., 2014). If companies want to effectively manage and implement business strategies, they need to get the right managers to perform the

\footnotetext{
* Corresponding author
} 
most important strategic functions. For any business, as to grow and prosper, managers must be able to anticipate, recognize and deal with change in the internal and external environment (Gallo et al., 2019; Ilieș et al., 2017). It should be noted, however, that unusual tourism not only entails risks but also helps increase competitiveness. Notable is the fact that tourism helps countries to secure their place on the international market while ensuring a higher standard of living for the population (Dobrovič et al., 2018). For qualified and correct answer how to achieve the higher efficiency and performance of business, it is firstly necessary to determine what the current and real business performance is and which appropriate and objective indicators use to measure this performance (Cabinova et al., 2018).

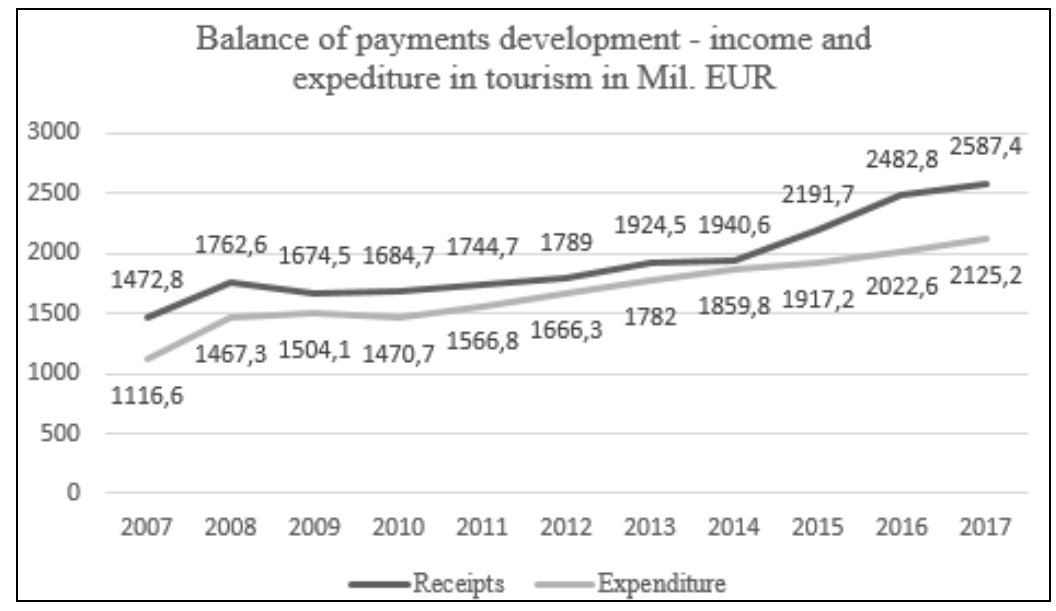

Figure 1. Balance of payments development in tourism (Source: own research)

\section{LITERATURE REVIEW}

Tourist behavior is a complex and widely-discussed issue, and there is still no generally accepted concept of tourist motivation. Understanding specific motives of tourists can help with products and services planning, more effective marketing communications, and improving and developing visitor attractions. There are many classifications, segments, and models that represent different themes. The differences between classifications of motives are essentially very large (Li and Cai, 2012; Šenková et al., 2016). Tourism is a special type of product that Witt and Mountinho (1994) analysed in two dimensions. In the first dimension, tourism is seen as a product that combines all services that tourists consume from the moment they leave the house until they return. According to these authors, tourism consists of five main components; destination's attractions, destination's facilities, accessibility, image and prices. They point out that tourism preferences of the present generation differ considerably from preferences in the past. Moutinho (2011) says there is a new generation of emerging travellers. They are motivated to discover something, are willing to explore different cultures as well as the fauna and flora of the given country. Tourists thus become explorers. Explorers need to explore exciting, and even risky actions to meet the need for knowledge and curiosity. Some people who experience less stimulus in their lives than they want tend to seek stimulus on vacation. On the contrary, over stimulated people are looking for peaceful vacation. This is what we call an optimal excitement - the ideal balance between lifestyle stimulation and vacation incentives (Stone, 2005). Holden (2005) came up with Maslow's hierarchical model (Figure 2), which was specially adapted for tourism sector. The underlying idea, however, stays the same. First of all, the needs at the lowest hierarchical level must be met so the needs at a higher hierarchical level could be met as well. The highest hierarchical level is self-realization, where tourism contributes to the personal development of an individual. In professional publications, we meet these main motives:

- regeneration - active and passive, spa and cures,

- exploration - culture, science, history, education, personality development,

research,

- contacts and ties - family, relatives, friends, religion and business.

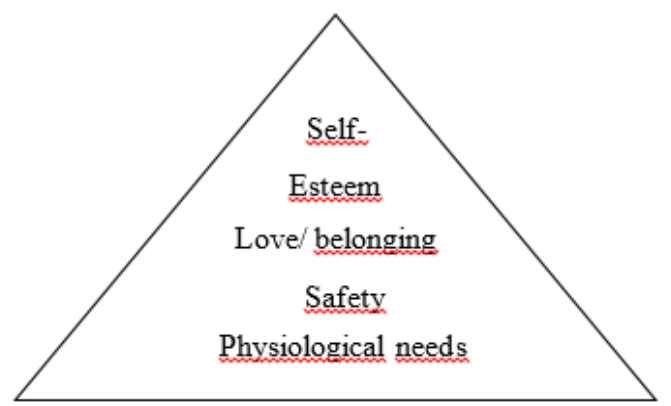

Figure 2. Maslow's hierarchy of tourism needs (Source: Holden, 2005)

The description of the individual needs:

- Self-actualisation: Tourism plays an important role in fulfilling an individual's values.

- Esteem: Self-esteem and social esteem. Various types of experience following one's travels. Relationships and acquaintances: they can strengthen our confidence. Travelling can build social recognition.

- Love/ belonging: The need to foster relationships with people is necessary for our well-being. Tourism can develop relationships with friends and family. It also provides an opportunity to build new friendships.

- Safety: Many people choose their destinations based on the safety level. Terrorism and a high degree of crime are factors that put off people from visiting. However, people who like to risk may be interested in these locations. 
- Physiological needs: Maslow's original model emphasizes the fulfilment of basic needs such as food, sex and accommodation. In the case of tourism, we talk about the need for relaxation and recovery, which are cited as the main reason for taking a holiday.

Motivation represents, according to Zelenka and Pásková (2012), a combination of internal stimuli and external stimuli (marketing, references) that leads people to do some activity. The criterion for choosing a particular form of tourism also affects the final satisfaction of the participant. Significant factors of motivation include push factors, including, for example, escape from everyday life, or relaxation, and pull factors that affect the choice of destination and its attractiveness. Participation in tourism is preceded by the needs and desires that determine the motivation of the participant (Čertík and Fišerová, 2009).

\section{UNUSUAL FORMS OF TOURISM}

Tourism is still evolving and changing, thus creating, in addition to the basic forms of tourism, new forms of itself that meet the special needs of the various specialized travel segments. Tourism is constantly changing, new forms of tourism are emerging, or the old ones are adapting to the latest trends, respond to changes in lifestyle (Internet, individualisation, independence, prolongation of active age). Specific forms of tourism are derived from specific activities that are the incentive for making a trip, ranging from specific needs to the age of participants (Ryglová et al., 2011).

Table 1. Examples of unusual forms of tourism (Source: own research, according to available literature)

\begin{tabular}{|c|c|}
\hline \multicolumn{2}{|r|}{ Examples of unusual forms of tourism } \\
\hline Food tourism & $\begin{array}{l}\text { The main motivation for tourism is gastronomy and food experiences (Jakubowska and Radzymińska, 2019). This may include } \\
\text { participation in specialized gastronomic events or food experiences, preparation and presentation of meals, familiarization with } \\
\text { gastronomic traditions in a given destination (Kotíková, 2013). }\end{array}$ \\
\hline Health tourism & $\begin{array}{l}\text { Tresidder }(2011, \text { p. } 268) \text { defines health tourism as "the medical treatment outside the country of tourist's residence where the } \\
\text { therapeutic element is the main subject of activities in the visited country“. }\end{array}$ \\
\hline Adventure tourism & $\begin{array}{l}\text { Adventure tourism is a form of tourism that entails a certain amount of risk (controlled), requires effort to overcome challenges } \\
\text { (physical, emotional, psychic), requires a degree of skill and generates strong emotions“ (Kotíková, 2013, p. 68). }\end{array}$ \\
\hline Dark tourism & $\begin{array}{l}\text { Dark tourism represents intermixture of history, heritage, tourism, and tragedies. We can argue that humanity has been interested } \\
\text { in , death” since the time of pilgrimages (Švedová et al., 2018). }\end{array}$ \\
\hline Event tourism & $\begin{array}{l}\text { Events include cultural events, festivals, summer music festivals, village performances (musical, theatre, others), concerts, } \\
\text { musicals, sporting events, folklore events, historical events, balls, religious events etc. (Kotíková, 2013). }\end{array}$ \\
\hline Volunteer tourism & $\begin{array}{l}\text { Volunteer tourism is one of the new forms of tourism. Many young people travel abroad to volunteer. The main reasons include } \\
\text { the possibility to travel to exotic countries. }\end{array}$ \\
\hline Wedding tourism & $\begin{array}{l}\text { Wedding tourism combines all activities connected with wedding and honeymoon. Wedding tourism is one of the most } \\
\text { dynamically developing branches of modern tourism. The most popular destinations are Greece, Italy, Mauritius, Seychelles, Sri } \\
\text { Lanka, Fiji, Cuba and Las Vegas (Syrovátková, 2013). }\end{array}$ \\
\hline Space tourism & Space tourism means space travel organized by a highly specialized, high-tech organization (Kotíková, 2013). \\
\hline Rural tourism & $\begin{array}{l}\text { It allows reviving traditional economic activities. It brings people together, strengthens the relationship with nature, consolidates health } \\
\text { and develops the need of the urban population to "return to the roots" (Babinský and Bujna 2015; Arintoko et al., 2020; Akay, 2020). }\end{array}$ \\
\hline Geocaching & Geocaching is a "treasure hunting" game that uses modern technologies. \\
\hline Shopping tourism & $\begin{array}{l}\text { The underlying idea is the joy of buying and the opportunity to browse new, unique goods (Syrovátková, 2013). Štefko and Steffek } \\
\text { (2018) point to the main motive of this kind of tourism, a fashion-like art that reflects the uniqueness of time, place and culture. }\end{array}$ \\
\hline Couchsurfing & $\begin{array}{l}\text { Couchsurfing is an international project that brings together people from all over the world. On the one hand, there are those who } \\
\text { are looking for a place to spend the night, and on the other, there are those who offer accommodation (Syrovátková, 2013). }\end{array}$ \\
\hline Fair tourism & $\begin{array}{l}\text { Fair tourism focuses on contractual and sales exhibitions of various products or services. Interest in this form of tourism is } \\
\text { declining slightly (Syrovátková, 2013). }\end{array}$ \\
\hline $\begin{array}{l}\text { Tourism of selected } \\
\text { groups }\end{array}$ & f tourism includes youth, senior and family tourism. A specific type of tourism is also the tourism of disabled people. \\
\hline Religious tourism & $\begin{array}{l}\text { It is clear from the title that this type of tourism is mainly based on the interest of visiting places of religious importance / } \\
\text { pilgrimage places. }\end{array}$ \\
\hline Hunting tourism & $\begin{array}{l}\text { It is mainly associated with hunting wild animals or birds. The main motives of participation in this form of tourism include } \\
\text { interest in hunting, wildlife, as well as psychological regeneration. }\end{array}$ \\
\hline Ascetic tourism & It is connected with a denial of enjoyment and delight. This form is often associated with religion. \\
\hline $\begin{array}{l}\text { Caravan tourism } \\
\text { and motorcycling }\end{array}$ & $\begin{array}{l}\text { Caravaning is considered by many authors to be a lifestyle. We know two subgroups - those who use caravans only during } \\
\text { holidays and others who have fully furnished caravans that are adapted to year-round traveling. Motorcycling is a specific form of } \\
\text { tourism, the goal becomes a way. The focus is placed on the vehicle. The fans of this form meet all over the world on motorbikes } \\
\text { (Syrovátková, 2013). }\end{array}$ \\
\hline
\end{tabular}

\section{MATERIALS AND METHODS}

The main objective of the paper is to analyse mainly unusual forms of tourism and their development in the territory of Slovakia. The partial objectives include the analysis of the demand for individual forms of tourism studied, as well as their popularity among the respondents. For the analysis of the specific objectives, we used data collected using a questionnaire on unusual forms of tourism and their development in Slovakia. The survey was carried out in 2018 on the territory of the Slovak Republic. We have chosen two ways to fill out the questionnaires. Some questionnaires were filled in in the printed form and some were filled in online using Gmail disk. The questionnaire was anonymous and voluntary. There were 16 questions of different types in the questionnaire. Respondents were free to express their own opinion on the basis of their personal experience. The first seven questions constitute dichotomous questions, i.e. questions with a clear answer. These questions are focused on the basic identification of the respondent and on its basic demographic data such as gender, age, country of origin, or education. One semi-open question was related to the country of origin of the respondent. The following questions were aimed at identifying the type of personality of the respondent that could influence the interest in individual unusual forms of tourism. The second part of our questionnaire is a standardized closed questions questionnaire using the verbal rating scale (Likert's technique of measuring attitudes in the questionnaire). Respondents have at their disposal a five-point scale where $1=$ strongly disagree, $5=$ strongly agree, $3=$ neutral. The above part of the questionnaire deals with specific unusual forms of tourism and attitudes of tourists towards them. 
The following part of the questionnaire deals with the motivation factors and the factors that influence the respondents when choosing a holiday. We processed the data obtained using Microsoft Office Excel and then the SPSS Statistica statistical program by IBM. This program has been instrumental in helping us to dig deep into the research problem. The survey was inspired mainly by our curiosity about the awareness of the unusual forms of tourism and, in particular, how could these form of tourism be supported and developed on the territory of Slovakia.

The following hypotheses were put under examination:

- H1: We assume that there is a statistically significant relationship between the age and the preference of the particular unu sual form of tourism.

- H2: We assume that there is a statistically significant correlation between one's personality (introvert, extrovert) and the preference of a particular form of tourism.

- H3: We assume that there is a statistically significant correlation between the financial situation of a person and his/her participation in tourism.

- H4: We assume that there is a statistically significant relationship between the sex of a person and his/her choice of a particular form of tourism.

\section{DESCRIPTION OF THE RESEARCH SAMPLE}

We chose our research sample based on the simple random selection process from among the tourism professionals. The basic set consists of statistical units - individuals. The survey was conducted on a sample of 360 respondents, both men and women of different age groups (16-62 years old). We did not impose any age restrictions. The research sample consisted of 222 women (67.1\%). The largest age group of respondents is made up of people aged 21-30. Respondents came from the Slovak Republic and from abroad (Czech Republic, Italy - 8 in total). Under each graph or table, the source must be provided and should be written in 10 pt. Leave 1 blank line between the graph or table and the source.

\section{RESULTS DISCUSSIONS}

In order to make sense of the results, we used the statistical methodology of the $p$ value comparison: if the value $p$ (asymptotic significance) is less than 0.05 , there is a significant dependence between the variables and we accept the hypothesis $\mathrm{H} 1$; if the value $\mathrm{p}$ is greater than 0,05 we do not reject the $\mathrm{H} 0$ hypothesis as there is a significant dependence between the variable categories.

If significant dependence is demonstrated, we interpret the coefficients as follows:

- Cramer's V - interval $\langle 0 ; 1\rangle$ without direction, symmetrical, non-linear.

- Gamma - interval <-1; $1>$ with direction, symmetrical, linear (suitable for nominal and ordinal scales).

Methodology interpretation: $0.01-0.09$ trivial to none, 0.10 - 0.29 low to medium, $0.30-0.49$ medium to strong, $0.50-0.69$ strong to very strong, $0,70-0.89$ very strong, $0.90-0.99$ almost perfect.

Hypothesis 1: We assume that there is a statistically significant relationship between the age and the preference of a particularly unusual form of tourism.

This variable "age" was divided into 5 intervals. The survey was attended by respondents aged 15-64. For the analysis, we used a gamma correlation coefficient ranging from -1 to 1 (symmetrical with the directive and linearity). In the following table, we tested these hypotheses by comparing $\mathrm{p}$-value:

- H0: there is no significant relationship between the categories of analysed variables.

- H1: there is a significant relationship between the categories of analysed variables.

Table 2. Hypothesis 1 testing (Source: own research)

\begin{tabular}{|c|c|c|c|c|c|}
\hline GAMMA & p-value & Recommendation & Dependency ratio & Interpretation & Direction \\
\hline Food tourism & 0,805 & H0 not to reject & $\mathrm{x}$ & stat. insignificant & $\mathrm{x}$ \\
\hline Health tourism & 0,150 & $\mathrm{H} 0$ not to reject & $\mathrm{x}$ & stat. insignificant & $\mathrm{x}$ \\
\hline Adventure tourism & 0,101 & $\mathrm{H} 0$ not to reject & $\mathrm{x}$ & stat. insignificant & $\mathrm{x}$ \\
\hline Dark tourism & 0,000 & reject $\mathrm{H} 0$ & $-0,399$ & medium & negat. \\
\hline Event tourism & 0,000 & reject $\mathrm{HO}$ & $-0,291$ & low to medium & negat. \\
\hline Volunteer tourism & 0,000 & reject $\mathrm{HO}$ & $-0,279$ & low to medium & negat. \\
\hline Wedding tourism & 0,000 & reject $\mathrm{HO}$ & $-0,403$ & strong & negat. \\
\hline Film tourism & 0,001 & reject $\mathrm{H} 0$ & $-0,189$ & low to medium & negat. \\
\hline Space tourism & 0,000 & reject $\mathrm{H} 0$ & $-0,225$ & low to medium & negat. \\
\hline Educational tourism & 0,523 & $\mathrm{H} 0$ not to reject & $\mathrm{x}$ & stat. insignificant & $\mathrm{x}$ \\
\hline Rural tourism & 0,053 & reject $\mathrm{HO}$ & $\mathrm{x}$ & stat. insignificant & $\mathrm{x}$ \\
\hline Geocaching & 0,028 & $\mathrm{H} 0$ not to reject & $-0,141$ & low to medium & negat. \\
\hline Shopping tourism & 0,107 & $\mathrm{H} 0$ not to reject & $\mathrm{x}$ & stat. insignificant & $\mathrm{x}$ \\
\hline Couchsurfing & 0,000 & reject $\mathrm{H} 0$ & $-0,249$ & low to medium & negat. \\
\hline Fair tourism & 0,760 & reject $\mathrm{H} 0$ & $\mathrm{x}$ & stat. insignificant & $\mathrm{x}$ \\
\hline Tourism of selected groups & 0,733 & $\mathrm{H} 0$ not to reject & $\mathrm{x}$ & stat. insignificant & $\mathrm{x}$ \\
\hline Religious tourism & 0,000 & $\mathrm{H} 0$ not to reject & $-0,289$ & low to medium & negat. \\
\hline Hunting tourism & 0,000 & $\mathrm{H} 0$ not to reject & $-0,284$ & low to medium & negat. \\
\hline Caravan tourism and motorcycling & 0,487 & H0 not to reject & $\mathrm{x}$ & stat. insignificant & $\mathrm{x}$ \\
\hline Ascetic tourism & 0,000 & $\mathrm{H} 0$ not to reject & $-0,303$ & strong & negat. \\
\hline
\end{tabular}

The test was performed by comparing the $p$ value - displayed in the column " $p$ value" $(0.05)$. As we can see in most cases, $p$-value is less than 0.05 . In these cases, it is recommended to reject the H0 hypothesis and accept its $\mathrm{H} 1$ alternative, which states that there is a significant dependence between the categories of analysed variables. In all these cases, we see a negative dependence, so we can say that with the rising age the preference of unusual forms of tourism declines, as we can see for the variable wedding tourism. Previous assertions about the significance of certain forms of tourism show that we should accept our basic hypothesis 1 . Therefore, we accept the fact that there is a statistically significant relationship between age and the preference of a particularly unusual form of tourism.

Hypothesis 2: We assume that there is a statistically significant correlation between one's personality (introvert, extrovert) and the preference of a particular form of tourism.

In the following table, we tested these hypotheses by comparing p-value: 
- H0: there is no significant relationship between the categories of analysed variables

- H1: there is a significant relationship between the categories of analysed variables

Table 3. Hypothesis 2 testing (Source: own research)

\begin{tabular}{|c|c|c|c|c|c|}
\hline GAMMA & p-value & Recommendation & Dependency ratio & Interpretation & Direction \\
\hline Food tourism & 0,004 & reject $\mathrm{H} 0$ & 0,183 & low to medium & pozit. \\
\hline Health tourism & 0,004 & reject $\mathrm{H} 0$ & 0,191 & low to medium & pozit. \\
\hline Adventure tourism & 0,215 & $\mathrm{H} 0$ not to reject & $\mathrm{x}$ & stat. insignificant & $\mathrm{x}$ \\
\hline Dark tourism & 0,216 & H0 not to reject & $\mathrm{x}$ & stat. insignificant & $\mathrm{x}$ \\
\hline Event tourism & 0,078 & H0 not to reject & $\mathrm{x}$ & stat. insignificant & $\mathrm{x}$ \\
\hline Volunteer tourism & 0,984 & H0 not to reject & $\mathrm{x}$ & stat. insignificant & $\mathrm{x}$ \\
\hline Wedding tourism & 0,002 & reject $\mathrm{HO}$ & 0,169 & low to medium & pozit. \\
\hline Film tourism & 0,015 & reject $\mathrm{H} 0$ & 0,184 & low to medium & pozit. \\
\hline Space tourism & 0,004 & reject $\mathrm{HO}$ & 0,178 & low to medium & pozit. \\
\hline Educational tourism & 0,174 & H0 not to reject & $\mathrm{x}$ & stat. insignificant & $\mathrm{x}$ \\
\hline Rural tourism & 0,136 & H0 not to reject & $\mathrm{x}$ & stat. insignificant & $\mathrm{x}$ \\
\hline Geocaching & 0,758 & $\mathrm{H} 0$ not to reject & $\mathrm{x}$ & stat. insignificant & $\mathrm{x}$ \\
\hline Shopping tourism & 0,000 & reject $\mathrm{H} 0$ & 0,274 & low to medium & pozit. \\
\hline Couchsurfing & 0,212 & H0 not to reject & $\mathrm{x}$ & stat. insignificant & $\mathrm{X}$ \\
\hline Fair tourism & 0,000 & reject $\mathrm{H} 0$ & 0,235 & low to medium & pozit. \\
\hline Tourism of selected groups & 0,000 & reject $\mathrm{H} 0$ & 0,22 & low to medium & pozit. \\
\hline Religious tourism & 0,192 & H0 not to reject & $\mathrm{x}$ & stat. insignificant & $\mathrm{x}$ \\
\hline Hunting tourism & 0,006 & reject $\mathrm{HO}$ & 0,202 & low to medium & pozit. \\
\hline Caravan tourism and motorcycling & 0,002 & reject $\mathrm{H} 0$ & 0,191 & low to medium & pozit. \\
\hline Ascetic tourism & 0,086 & H0 not to reject & $\mathrm{x}$ & stat. insignificant & $\mathrm{x}$ \\
\hline
\end{tabular}

As far as the analysed set is concerned, we have accepted in several cases the hypothesis H1, since in some cases p-value was less than 0.05 . Based on this fact, our basic hypothesis 2 can also be accepted. We accept the view that there is a statistically significant relationship between the respondent's personality (introvert, extrovert) and the preference of a particular form of tourism.

Hypothesis 3: We assume that there is a statistically significant correlation between the financial situation of a person and his/her participation in tourism.

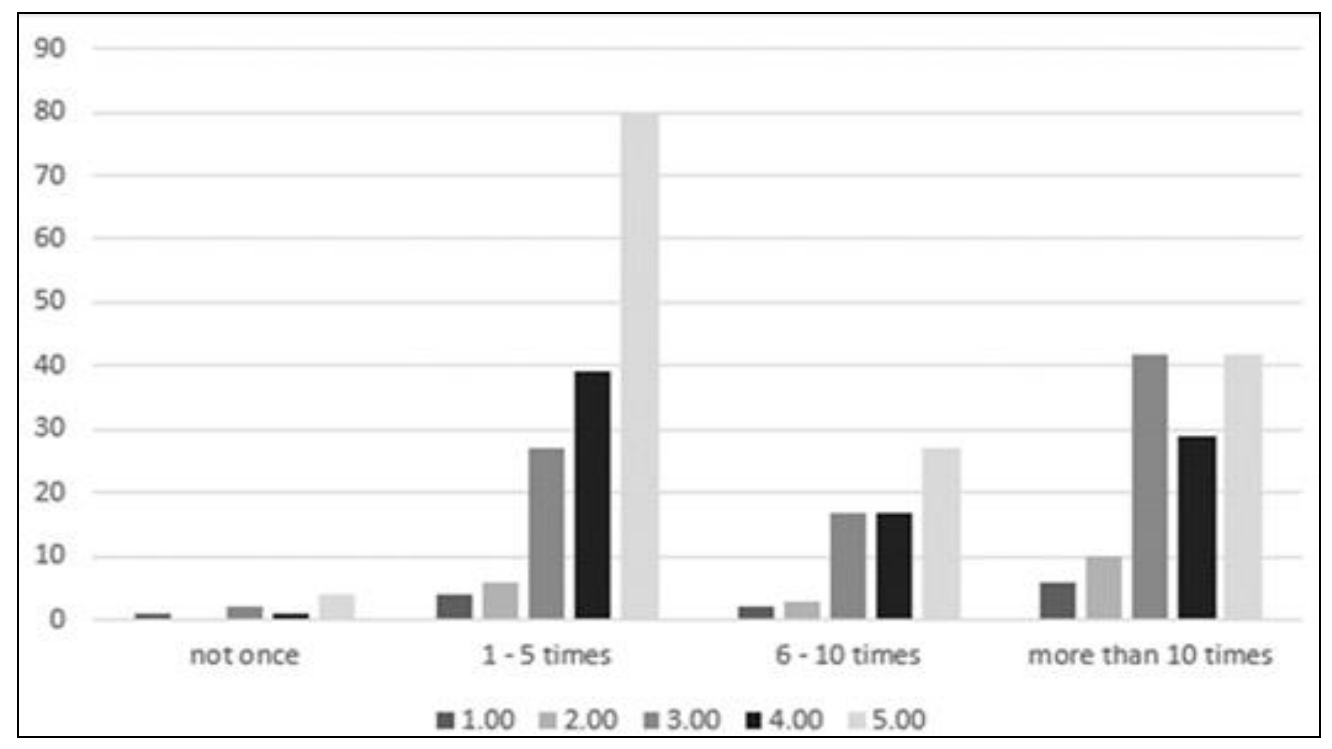

Figure 2. Analysis of the impact of the financial situation by frequency and number (Source: own research)

Table 4. Hypothesis 3 testing (Source: own research)

\begin{tabular}{|l|c|c|c|c|c|c|}
\hline Question: Please indicate how your financial situation has influenced your choice \\
\hline Frequency & $\mathbf{1 , 0 0}$ & $\mathbf{2 , 0 0}$ & $\mathbf{3 , 0 0}$ & $\mathbf{4 , 0 0}$ & $\mathbf{5}$ & In total \\
\hline not once & 1 & 0 & 2 & 1 & 4 & 8 \\
\hline $1-5$ times & 4 & 6 & 27 & 39 & 80 & 156 \\
\hline 6 - 10 times & 2 & 3 & 17 & 17 & 27 & 66 \\
\hline more than 10 times & 6 & 10 & 42 & 29 & 42 & 129 \\
\hline in total & 13 & 19 & 88 & 86 & 153 & 359 \\
\hline
\end{tabular}

- H0: there is no significant relationship between the categories of analysed variables.

- H1: there is a significant relationship between the categories of analysed variables.

Table 5. Hypothesis 3 testing - Symmetric Measures (Source: own research)

\begin{tabular}{|c|c|c|c|c|}
\hline & Value & Asymptonic Standardized Error & Approximate $^{\mathrm{b}}$ & Approximate Significance $^{\mathrm{a}}$ \\
\hline Ordinal by Ordinal Gamma & $-0,250$ & 0,066 & $-3,715$ & 0,000 \\
\hline $\mathrm{N}$ of Valid Cases & 359 & & & \\
\hline
\end{tabular}


- A: 0 hypotheses is not expected.

- B: use asymptotic standard error assuming a zero hypothesis.

The value shown in the last column of the table (zero) suggests that it is appropriate to reject the hypothesis H0 and accept its H1 alternative. This fact also goes well with our basic hypothesis 3 , which we thus accept with the view that there is a statistically significant relationship between the financial situation of a person and his/her participation in tourism. As can be seen, the degree of dependence is negative, so we can say that the higher the frequency of tourism, the smaller the role financial situation plays. The corresponding dependence can be interpreted as moderate.

Hypothesis 4: We assume that there is a statistically significant relationship between the sex of a person and his/her choice of a particular form of tourism.

The hypothesis focuses on the dependence of the variable sex and the preference of the unusual forms of tourism. The sex is found in the nominal scale with dichotomous categories, so the use of Cramer V correlation coefficient is appropriate for the analysis of dependence. This coefficient analyzes the dependencies of the dependent variables in the range 0 to 1 (without direction and symmetry but with linearity). The following table verifies statistical significance using the following hypotheses:

- H0: there is no significant relationship between the categories of analysed variables.

- H1: there is a significant relationship between the categories of analysed variables.

Table 6. Hypothesis 4 testing (Source: own research)

\begin{tabular}{|c|c|c|c|c|}
\hline GAMMA & p-value & Recommendation & Dependency rate & Interpretation \\
\hline Food tourism & 0,072 & reject H0 & $\mathrm{x}$ & low to medium \\
\hline Health tourism & 0,000 & reject $\mathrm{H} 0$ & 0,278 & low to medium \\
\hline Adventure tourism & 0,813 & H0 not to reject & $\mathrm{x}$ & stat. insignificant \\
\hline Dark tourism & 0,840 & H0 not to reject & $\mathrm{x}$ & stat. insignificant \\
\hline Event tourism & 0,153 & $\mathrm{H0}$ not to reject & $\mathrm{x}$ & stat. insignificant \\
\hline Volunteer tourism & 0,080 & H0 not to reject & $\mathrm{x}$ & stat. insignificant \\
\hline Wedding tourism & 0,010 & reject H0 & 0,193 & low to medium \\
\hline Film tourism & 0,014 & reject $\mathrm{H} 0$ & 0,186 & low to medium \\
\hline Space tourism & 0,267 & H0 not to reject & $\mathrm{x}$ & stat. insignificant \\
\hline Educational tourism & 0,000 & reject H0 & 0,26 & low to medium \\
\hline Rural tourism & 0,517 & H0 not to reject & $\mathrm{x}$ & stat. insignificant \\
\hline Geocaching & 0,024 & reject $\mathrm{H} 0$ & 0,177 & low to medium \\
\hline Shopping tourism & 0,000 & reject $\mathrm{H} 0$ & 0,257 & low to medium \\
\hline Couchsurfing & 0,027 & reject $\mathrm{HO}$ & 0,175 & low to medium \\
\hline Fair tourism & 0,150 & $\mathrm{H} 0$ not to reject & $\mathrm{x}$ & stat. insignificant \\
\hline Tourism of selected groups & 0,791 & $\mathrm{H} 0$ not to reject & $\mathrm{x}$ & stat. insignificant \\
\hline Religious tourism & 0,040 & reject $\mathrm{H} 0$ & 0,167 & low to medium \\
\hline Hunting tourism & 0,003 & reject $\mathrm{H} 0$ & 0,211 & low to medium \\
\hline Caravan tourism and motorcycling & 0,873 & H0 not to reject & $\mathrm{x}$ & stat. insignificant \\
\hline Ascetic tourism & 0,958 & $\mathrm{H0}$ not to reject & $\mathrm{x}$ & stat. insignificant \\
\hline
\end{tabular}

In several cases in the analyzed set, we adopted the hypothesis H1, since in these cases p-value was less than 0.05 . Based on this fact, our basic hypothesis 4 can also be adopted, as there is a statistically significant relationship between the sex of a person and his/her choice of a particular form of tourism.

\section{CONCLUSION}

Based on the survey results, we reached the following conclusions:

- According to hypothesis 1 , we can assert that there is a statistically significant relationship between the age of our respondents and their preference for a particularly unusual form of tourism. With the increasing age of the respondents the interest in unusual forms of tourism declines.

- Hypothesis 2 confirms that there is a statistically significant relationship between the personality of a respondent (introvert, extrovert) and the preference for a particularly unusual form of tourism. Most of the respondents are extrovert.

- According to hypothesis 3 , we can conclude that there is a statistically significant relationship between the financial situation of a person and his/her participation in tourism - medium dependency.

- Hypothesis 3 also confirms that there is a statistically significant relationship between the sex of a person and his/her choice of a particular form of tourism.

Based on these findings we can conclude that it is necessary to take into account the above-mentioned aspects when placing tourism products on the market. Each offer has to be very sensitively formulated to address the particular target group and its desires.

\section{Aknowlegments}

This work was supported by research grant VEGA No. 1/0470/18 "Economic activity of tourism in the European area".

\section{REFERENCES}

Akay, B. (2020). Examining the Rural Tourism Experiences of Tourists in Emerging Rural Tourism Destination: Burdur Province, Turkey. GeoJournal of Tourism and Geosites, 29(2), 534-544.

Arintoko, A., Ahmad, A.A., Gunawan, D.S., Supadi, S. (2020). Community-Based Tourism Village Development Strategies: a Case of Borobudur Tourism Village Area, Indonesia. GeoJournal of Tourism and Geosites, 29(2), 398-413.

Babinský, M., \& Bujna, M. (2015). Quality features for tourism and agro-tourism facilities: EZAT.

Belás, J., Machacek, J., Bartos, P., Hlawiczka, R., \& Hudakova, M. (2014). Business Risks and the Level of Entrepreneurial Optimism among SME in the Czech and Slovak Republic. Journal of competitiveness, 6(2), 30-41.

Błażejowski, M., Kwiatkowski, J., \& Gazda, J. (2019). Sources of economic growth: A global perspective. Sustainability, 11(1), 275.

Cabinova, V., Onuferova, E., Gallo Jr,P., Gallo, P., \& Gallo, J. (2018). A comparative analysis of modern performance methods in economic practice. Montenegrin Journal of Economics, 14(4), 85-96. 
Čertík, M., \& Fiserova, V. (2009). Leisure, lifestyle and tourism. Praha: Institute of Hospitality Management in Prague.

Draskovic, M., Draskovic, V., Bilan, Y., \& Delibasic, M. (2016). Quasi-neoliberalism as quasi institutional monisms and causes of the crisis in south-eastern Europe. Transformations in Business and Economics, 15 (2B), 755-765.

Drosos, D., \& Tsotsolas, N. (2015). Customer satisfaction evaluation for Greek online travel agencies. Hospitality, travel, and tourism: Concepts, methodologies, tools, and applications, IGI Global, (pp. 860-879).

Dobrovič, J., Urbański, M., Gallo, P., Benková, E. \& Čabinová, V. (2018). Balanced scorecard concept as a tool of strategic management and its usage in the construction industry. Polish Journal of Management Studies, 18(2), 59-72.

Gallo, P., Cabinová, V., Onuferová, E., Gallo, P. \& Gallo, J. (2019). The influence of leadership style on the work activity of employees in the selected financial institution. Quality - Access to Success, 20 (170).

Ginevicius, R. (2019). Quantitative Assessment of the Compatibility of the Development of Socioeconomic Systems. Journal of Competitiveness, 11(2), 36-50.

Holden, A. (2005). Tourism studies and the social sciences. Abingdon: Oxon.

Ilieș, D.C., Baias, S., Buhas, R., Ilieș, A., Herman, G.V., Gaceu, O., Dumbravă, R., Măduţa F. (2017). Environmental Education in Protected Areas. Case Study from Bihor County, Romania. GeoJournal of Tourism and Geosites, 1(19), 126-132.

Jakubowska, D., \& Radzymińska, M. (2019). Health and environmental attitudes and values in food choices: a comparative study for Poland and Czech Republic. Oeconomia Copernicana, 10(3), 433-452.

Kotíková, H. (2013). New trends in tourism offer. Praha: Grada Publishig.

Li, M., \& Cai, L. A. (2012). The effects of personal values on travel motivations and behavior intention. Journal of Travel Research, 51(4), 473-487.

Moutinho, L. (2011). Strategic management in tourism. Printed and bound in the UK by Cambridge University Press, Cambridge.

Pachura, P., Nitkiewicz, T., Matlovičová, K., \& Matlovič, R. (2018). Identification of intellectual capital performance using data envelopment analysis. In Knowledge Spillovers in Regional Innovation System,s Springer, Cham, (pp. 115-130).

Piotrowska, M. (2019). Facets of competitiveness in improving the professional skills. Journal of Competitiveness, 11(2), 95-112.

Ryglová, K., Burian, M., \& Vajcnerova, I. (2011). Tourism - business principles and opportunities in practice. Praha: Grada Publishing.

Stone, P.

R. (2005). Dark tourism consumption: A call for research. e-Review of Tourism Research, 3(5), 109-117.

Suchanek, P., Kralova, M. (2018). The Influence of Costumers' Personal Characteristics on their Satisfaction with the Food Industry. Journal of Competitiveness, 10(4), 151-170.

Syrovátková, J. (2013). Specific forms of tourism. Liberec: University of Technology in Liberec.

Šambronská, K., Matusikova, D., Gallo, P., Šenková, A., \& Mitríková, J. (2016). Hotel Services - Quality Base Of Dimension Of Service. BK 2: Political Sciences, Law, Finance, Economics and Tourism Conference Proceedings, 4, 307-314.

Šenková, A., \& Sambronska, K. (2014). Hotel and restaurant management (selected chapters). Presov: Bookman.

Šenková, A., Sambronska, K., Mitrikova, J, Matusikova, D., \& Matkova, S. (2016). Corporate culture as a tool for increasing employee motivation. Polish Journal of Management Studies, 13(2), 131-141.

Štefko, R., \& Steffek, V. (2018). Key Issues in Slow Fashion: Current Challenges and Future Perspectives. Sustainability, 10(7).

Švedová, M., Uher, I., \& Dzurov Vargova, T. (2018). Dark tourism incentive. Studia Turistica. College of Polytechnics Jihlava. 9(3), $120-128$.

Tresidder, R. (2011). Medical tourism. Londýn: CAB Internacional.

Zelenka, J., \& Paskova, M. (2012). Glossary of tourism. Praha: Linde.

Witt, S.F., Moutinho, L. (1994). Tourism marketing and management handbook. Upper Saddle River: Prentice. p. 617. 